\title{
Coral bioherms below the euphotic zone in the Red Sea
}

\author{
Hans W. Fricke ${ }^{1}$ and Lukas Hottinger ${ }^{2}$ \\ ${ }^{1}$ Max-Planck-Institut für Verhaltensphysiologie, D-8131 Seewiesen, Federal Republic of Germany \\ ${ }^{2}$ Geological Institute, Bernoullistr. 32, CH-4056 Basel, Switzerland \\ and Heinz-Steinitz-Marine Laboratory, Eilat, Israel
}

\begin{abstract}
During exploration of the narrow Western shelf in the Gulf of Aqaba by means of the research submersible 'GEO', bioherms formed by the stony coral Madracis interjecta were discovered between $120 \mathrm{~m}$ and at least $200 \mathrm{~m}$ depth. The growth of the bioherms is supposed to be linked to the particularly warm-temperature regime of the Gulf of Aqaba, whereas distribution depends probably on current patterns (providing nutrients), submarine topography and availability of hard substrate. The absence of symbiotic algae below the euphotic zone does not hamper the building of bioherms by stony corals. The Madracis-bioherms are true reefs in the definition of the term by the Earth Science in as much as the bioherms are surrounded by selected detritic facies types similar to ordinary, sheltered patch reefs in the photic zones.
\end{abstract}

\section{INTRODUCTION}

Below the depths accessible to Scuba divers (ca. $70 \mathrm{~m}$ ), visual control of the explaration of the sea bottom must be carried out by remote-controlled, submersible video devices or by submarines in order to interpret correctly sampling and measurements carried out by surface vessels. Submarines have the advantage of permitting immediate sampling of the sea bottom as a function of what is observed during the dive under direct visual control. A sampling spot at the sea bottom can thus be selected with an accuracy of a few centimeters or less. This is important when the seabottom is structured by a mosaic of small units of different substrates and, in particular, at the limits between hard and soft bottoms.

From August 1981 to April 1982, a diving survey with the research submersible 'GEO' revealed an unsuspected nature of the narrow Western shelf in the northern and southern parts of the Gulf of Aqaba (Elat, Israel) down to about $200 \mathrm{~m}$ depth: Large surfaces of this shelf are not covered by sediments but by hard substrates on which sessile communities luxuriantly grow. In particular, sediment-binding frameworks of colonial corals were discovered. This is the first record of coral bioherms below the euphotic zone in the Red Sea. It is the aim of this report to illustrate and describe these coral structures and to discuss some of the conditions limiting their distribution.

\section{FRAME BUILDING CORALS}

Samples of frame-building corals taken with the manipulator of 'GEO' were identified as the pocilloporid Madracis interjecta (v. Marenzeller, 1906). Earlier records of this coral are restricted to von Marenzeller's dredgings in the Red Sea from 168 and $350 \mathrm{~m}$ depth. The shallowest of about 40 records by photography from 'GEO' are $122 \mathrm{~m}$ in southern Sinai (Mersa al At) and $131 \mathrm{~m}$ in the Northern part of the Gulf of

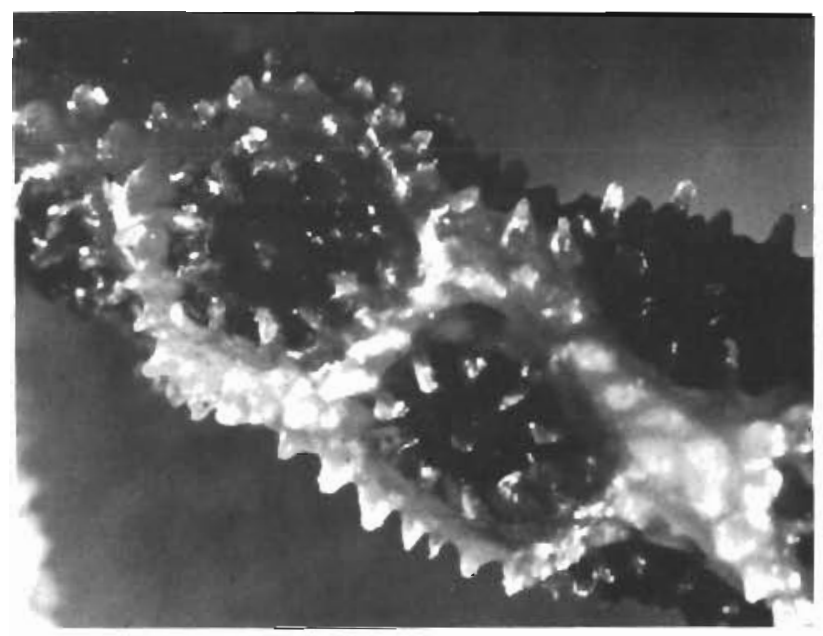

Fig. 1. Madracis interjecta. Polyp diameter ca. $1 \mathrm{~mm}$ the polyp tissue becomes reddish when in contact with air 


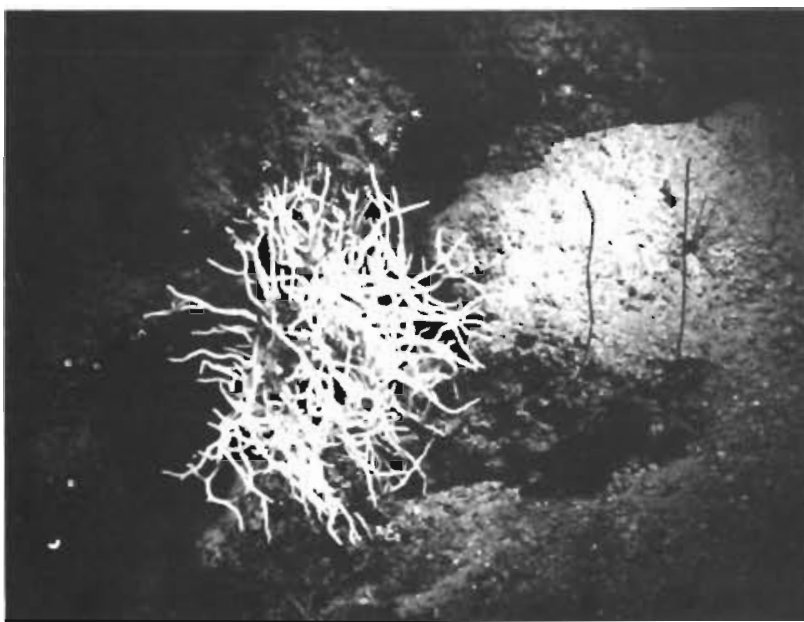

Fig. 2. Madracis interjecta. Single living colony growing on hard substrate partially covered with sand

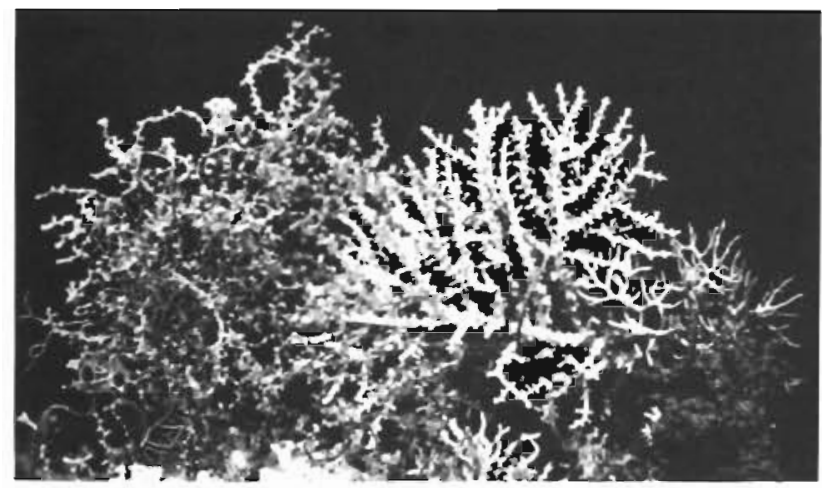

Fig. 3. Dendrophyllia cf. minuscula and $M$. interjecta are the only framebuilding ahermatypic corals of the Gulf of Aqaba. Left: unidentified octocoral. Depth: $166 \mathrm{~m}$

Aqaba. Living coral colonies are perfectly white (Fig. 2); when dried, their soft parts turn reddish. $M$. interjecta has no symbionts as one may conclude from the transparent aspect of the living tissue. Less frequently, Dendrophyllia of. minuscula Bourne plays a similar part as frame builder (Fig. 3).

Madracis interjecta has an acroporid habit of forming irregular dense bushes of slender, pointed branches (Fig. 2). There is no obvious orientation in the direction of branch growth. In Dendrophyllia minuscula the branches form large fans. Usually, the 2 frame builders do not build bioherms in common. $M$. interjecta occurs in form of single coral colonies (Fig. 2). Large blocks of cemented branches may often be overgrown by numerous living colonies (Fig. 4). By forming a common thicket, the bioherms are elevated up to $2 \mathrm{~m}$ above the level of soft sediment surrounding the coral structure. Their largest horizontal diameter may reach $5 \mathrm{~m}$. Bioherms of $D$. minuscula are usually smaller (Fig. 3).
The living frame builders are usually encrusted at their base. In Madracis interjecta skeletons, often a few $\mathrm{cm}$ long tips are covered by the living tissue of the coral whereas the rest of the colony is already covered by other organisms characteristic of the $M$. interjecta habitat.

\section{LIVING CONDITIONS}

Madracis interjecta bioherms occur in the northern part of the Gulf of Aqaba below $120 \mathrm{~m}$ and down to at least $200 \mathrm{~m}$ depth, on the shelf edge. Light measurements with a Lambda photometer ( $\mathrm{Li}$ 185) and sensor Li $192(400-700 \mathrm{~nm})$ revealed that $0.5 \%$ of the surface light intensity is the upper limit of its occurrence. This also happens to represent approximately the lower limit of the photosynthetically active scleractinian coral Leptoseris fragilis Milne-Edwards \& Haime
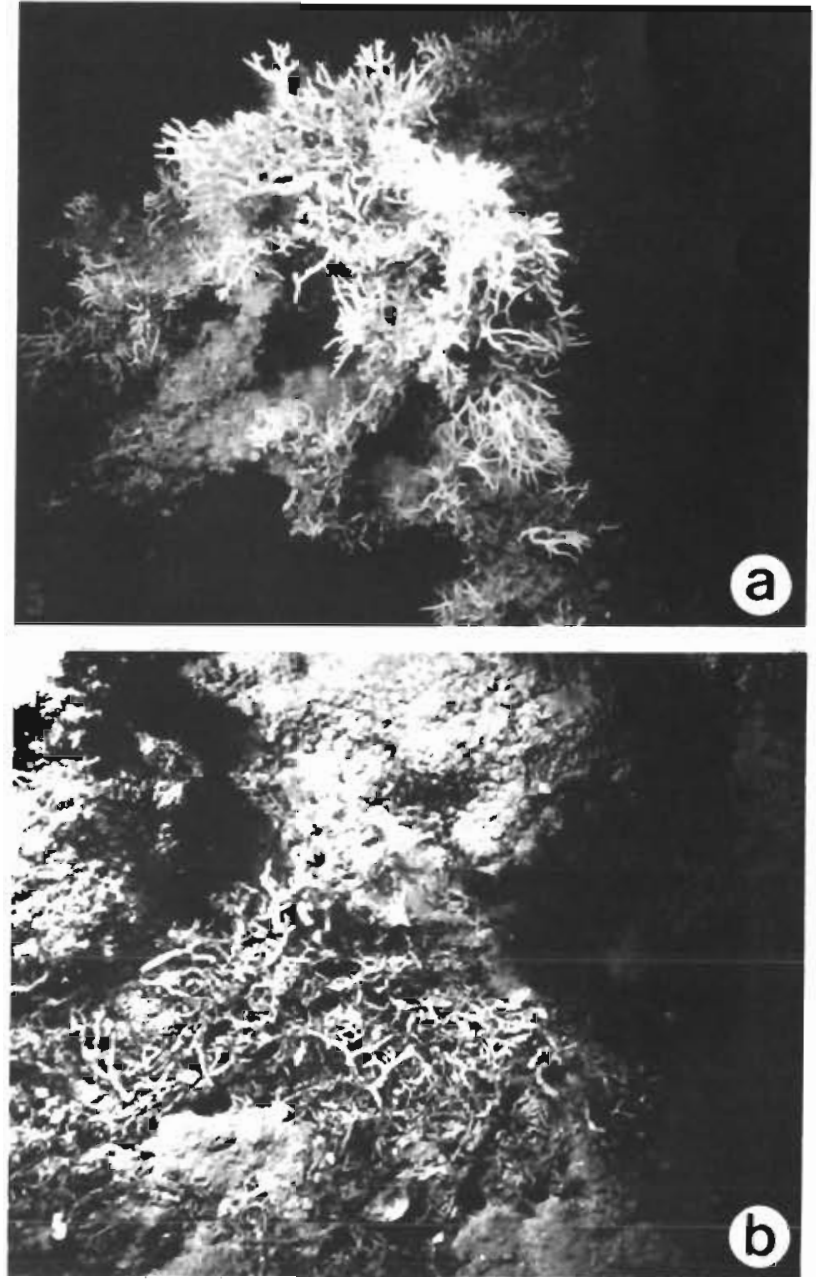

Fig. 4. Madracis interjecta. (a) Monotypic bioherm. The bioherm base consists of calcified specimens; living colonies are white; depth: $165 \mathrm{~m}$. (b) Remnants of dead colonies littering the base of the same bioherm; depth $165 \mathrm{~m}$ 
(Fricke, unpubl.), of the larger foraminifera carrying vegetal symbionts (Hottinger, 1977) and of coralline, red and brown algae.

Minimum water temperatures measured by 'GEO' during winter near the sea bottom at $100 \mathrm{~m}$ depth were $21.7^{\circ} \mathrm{C}$ and at $203 \mathrm{~m}, 21.8^{\circ} \mathrm{C}$. This is in good agreement with the measurements taken nearby in the open water by Klinker et al. (1976, Station A) and by Paldor and Anati (1979). Considering the current pattern in the gulf, probably other parameters (salinity, oxygen, nutrients) measured at Station A by Klinker et al. (1976, 1978) apply also for the exposed parts of the shelf edge where the bioherms occur.

Diving at noon with 'GEO' during September and October permitted us to observe the upper limit of the main plankton layer forming a clearly delimited cloudy surface in the water column at $95 \mathrm{~m}$, as observed during Dive 54 when no current was perceived. Therefore, the Madracis interjecta habitat seems not to be exposed to daily plankton migration as are higher parts of the coral carpets and reefs along the coast.

The hard substrate on which Madracis interjecta and Dendrophyllia minuscula grow as frame builders, is a biogenous construction of coarse fragments of the frame builders and/or of bryozoans, together with mollusc and foraminiferan shells and smaller debris of the epizoan fauna (Fig.5). They are cemented first by

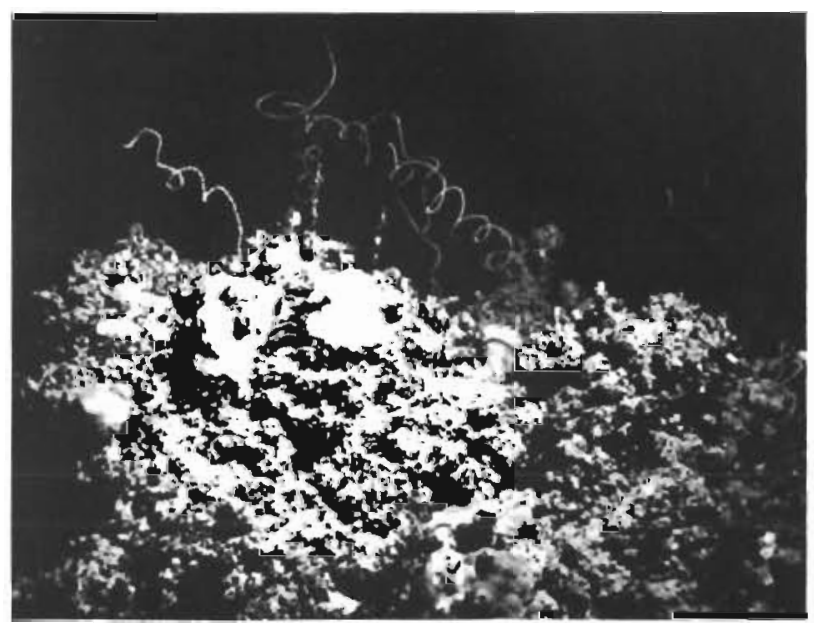

Fig. 5. Fossilized Madracis bioherm with secondary settlers, mainly antipatharian corals and small ahermatypic species

encrusting vermitids and bryozoans and filled up later by smaller grains and inorganic cements of calcite crystals with very low contents of magnesium. Cementation of the substrate is so strong that even bumping against prominent structures with the submarine only in exceptional cases damaged the substrate. In thin sections, 2 generations of calcitic cement can be distin- guished. In some places, the primary porosity of the biogenous construction is filled up almost completely by inorganic cements, but this filling is very irregular and cannot be compared to hard-ground cements as observed in the fringing reefs in shallow depths. Despite the brownish colour of the cemented surfaces, no traces of metal- (particularly iron-) oxides were found in the samples taken by 'GEO'. The thickness of the biogenous hard substrate over the bedrocks is not yet known. In the northern part of the Gulf of Aqaba no outcrops of bedrock were observed at the shelf edge.

Between relief highs, in hollows, on terraces and along valleys or depressions perpendicular to the slope, mobile sediments are deposited. The thickness of the soft sediments over the hard substrate is not known. Around the outcropping hard substrate, however, the manipulator of the submarine always encountered hard bottom at 5 to $15 \mathrm{~cm}$ below the sediment surface. The coarser fractions of the sediment (fine sand to sand) consist of biogenous particles, the finer, pelitic fractions of coccolith oozes. Terrigenous clays form a very small percentage of the dry weight of the sediment: The proportion of soluble (in $\mathrm{HCl}$ ) to insoluble fractions of the total sediment are 1:0.06 at $125 \mathrm{~m}$ depth, $1: 0.025$ at $192 \mathrm{~m}$. Planktonic and benthic organisms participate by their production of shells in the formation of the sediment and determine the distribution of grain sizes.

On more or less horizontal surfaces, the sediments are inhabited by a considerably dense infauna burrowing in the substrate. The surfaces of sediments deposited on steep slopes are smooth showing no trace of infaunal life. Epifauna is scarce with the exception of small incrusting animals growing on coarse shell debris. Macroids were not observed in depths below $100 \mathrm{~m}$. This indicates that the linear currents never reach sufficient energy to lift and turn over coarser shell debris during the yearly cycle (Hottinger, 1982).

In the southern part of the Gulf of Aqaba, south of the Straits of Tiran, Madracis interjecta is very rare: In 109 dives along the steep slopes of the tip of Sinai Peninsula single colonies of $M$. interjecta were encountered only twice.

\section{FAUNAL ASSEMBLAGE IN THE MADRACIS INTERJECTA BIOHERMS}

The rigid framework built by Madracis interjecta or Dendrophyllia minuscula furnishes niches for a large variety of other benthic, mostly sessile animals. The majority of these adopt a strategy of passive filter feeding. Animals feeding by active pumping, such as brachiopods and sponges, are in a minority and inhabit hidden cavities of the framework. New, hard substrate 
is colonized first by the omnipresent vermetids, bryozoans, sessile foraminiferans and sometimes by cirripeds. A considerable number of small, ahermatypic corals settles later on such encrusted fauna. However, the contribution of these corals to growth of the bioherm is not important. The corals were identified by G. Scheer as Javania insignis Duncan 1876, Balanophyllia cumingii M. Edwards \& Haime 1848 , Rhizotrochus typus M. Edwards \& Haime 1848, Dactylotrochus cervicornis Moseley 1881 and Phyllangia sp. Antipatharians and comparatively small sponges help to catch and fix mobile sediment in the framework but do not contribute much to the mineralized building. The most productive mineralizers of carbonate are doubtlessly the lamellibranchs fixed by byssus strings to the substrate: The shells of the pteriid Pterelectroma sp. and of several species of the arcacean and pectinacean superfamilies dominate the thanatocoenoses accumulated in and around the bioherms. Together with the shells of the sessile foraminifera Miniacina sp., Homotrema sp. and Sporadotrema sp., they are good indicators of the existence of hard substrate in the vicinity of the spot where samples of soft sediments were taken from surface vessels, without visual control, as for instance off Geziret Faraoûn (Coral Island), where the shelf is broader than usual (Hottinger 1977).

\section{DESTRUCTION OF THE BIOHERM AND SEDIMENTATION OF ORGANIC DEBRIS}

Unlike in coral reefs exposed to surface waters, the destruction of Madracis interjecta and Dendrophyllia minuscula bioherms is slow and largely due to the biological activity of a selection of boring organisms of all sizes from large Lithophaga to unidentified boring sponges. Their action, combined with the overload of encrusting organisms on dead branches and with the gentle pressure of slow currents, results in an unsorted, chaotic accumulation of larger debris around the bioherm (Fig. 4) filled up partially with the smaller and larger shells of loosely attached or free epizoans and pellets. Thin sections of the cemented substrate reveal that the finest sediment fraction captured must be winnowed out of the framework during maximum current velocities. The destruction of the bioherm thus produces considerable amounts of new, hard substrate to be overgrown again by new settlements of $M$. interjecta colonies. The core of the bioherm is surrounded by a coarse, biodetritic facies similar to small patch reefs in sheltered surface waters. The fossil product might be difficult to distinguish from such shallower reefs when the main framebuilder cannot be specifically identified. Compared to patch reefs in shallow water, however, the sediment trapped in the framework of a deepwater bioherm contains much higher numbers of shells derived from the plankton. This is in agreement with the sediments observed in much deeper (1000-1300 m) bioherms occurring north of little Bahama Bank (Mullins et al. 1981).

\section{DISCUSSION}

Coral bioherms in depths below the euphotic zone have been reported from many places in the North and Middle Atlantic Ocean (summaries in Teichert, 1958 and Wilson, 1979), from the European shelf in the East Atlantic Ocean (Wilson, 1975), from the West Indian region and the Gulf of Mexico (More and Bullis, 1960), the Blake Plateau (Stetson et al., 1962), from New Zealand (Squires, 1965), from the Niger Delta (Allan and Wells, 1962) and from the Mediterranean Sea (Bourcart, 1952, 1953). Most of these reefs are formed by various species of Lophelia living in temperature ranges from 4 to $8^{\circ} \mathrm{C}$ (Teichert, 1958) or, in the Gulf of Mexico, in waters up to $10.4^{\circ} \mathrm{C}$ (Moore and Bullis, 1960). In the Gulf of Aqaba, temperatures below the photic zone are about $10 \mathrm{C}^{\circ}$ higher. This might be the reason for finding another dominant frame builder, Madracis interjecta, in this particular habitat.

The distribution of Madracis interjecta bioherms depends on supplementary factors: Their quasi absence in the southern part of the Gulf, where similar temperatures and substrates are available at comparable depths, corresponds to very low nutrient concentrations in the water column below the outflowing watermasses at the bottom of the Straits of Tiran (values for Station $\mathrm{H}$ in Klinker et al. 1978). Considering these distributions of nutrients and consequently of plankton biomass in the water body of the gulf and keeping in mind the total heterotrophy of the main frame builder (due to its lack of symbionts), its morphology as a typical passive filter feeder and its association with many other passive filter feeders, we may safely assume an ecological link between the density of $M$. interjecta and the density of planktonic food organisms carried by the current. The presence of Dendrophyllia minuscula sharing the same general habitat with $M$. interjecta is another hint as to the importance of the current: The distribution of various Dendrophyllia species in shallower, euphotic waters strinkingly depends on the exposure of their substrate to regular currents as observed by SCUBA diving in the Maledivas or in New Caledonia. In the Gulf of Aqaba also, D. minuscula occurs on steep slopes or on terrace edges swept by currents. All these arguments lead to the conclusion that the current pattern in the gulf is responsible for the distribution of the bioherms below the euphotic zone, providing food to the frame 
building community and, at the same time, a suitable substrate by cleaning the hard surfaces from the finer sediment fractions and by keeping the rate of sedimentation comparatively low.

Coral-reef biologists differentiate between reefbuilding (hermatypic) and non-reefbuilding (ahermatypic) corals. The construction of large bioherms in shallow water is said to be linked to the presence of symbiontic algae, the zooxanthellae. Below the euphotic zone, however, very different, genetically unrelated species lacking symbionts build ramified, larger, colonies similar to those of hermatypic corals. Whatever these build-ups below the photic zone might be called (e.g. coral banks, Teichert, 1958; -structures, Wilson, 1979 ; -architecture, Squires, 1965; -mounds, Mullins et al., 1981), their mechanism of formation is the same: The frame builder mineralizes calcium carbonate to support a rigid colony without help of vegetal symbionts at rates permitting the growth of the colony to exceed the accumulation of sediment. The physiological stress to fix calcium carbonate in form of a mineralized skeleton without symbionts does not seem to be a limiting factor at all, at least not for the frame building species: In contrast to the ahermatypic corals sharing habitat and substrate with Madracis interjecta or Dendrophyllia minuscula in the Gulf of Aqaba, both frame builders form very solid and massive skeletons. This is in contrast also to the skeletons of the deepest symbiont-bearing coral species between 60 and $120 \mathrm{~m}$ depth, all of which are characterized by devices to economize mineralized calcium carbonate in their skeleton, i.e. by adapting monolayered flat growth forms.

Acknowledgements. Diving operations with the research submersible 'GEO' in the northern part of the Gulf were based at the $\mathrm{H}$. Steinitz Marine Biology Laboratory, Elat, a marine station of the Hebrew University. They were subsidized by the Deutsche Forschungsgemeinschaft (Project No. Fri 369/5) and the Swiss National Science Foundation (Project No. 2.474.079). This financial help is gratefully acknowledged. Dr. Scheer, Darmstadt, Federal Republic of Germany, Kindly identified the corals.

\section{LITERATURE CITED}

Allan, J. R. L., Wells, J. W. (1962). Holocene coral banks and subsidence in the Niger Delta. J. Geol. 70: 381-397

Bourcart, J. (1952). Rapports sur les canons sous-marins de la Région de Banyuls-sur-Mer Vie Milieu (Suppl. 2, Océanogr Méditerranéenne): 165-168

Bourcart, J. (1953). Contribution à la connaissance du socle sous-marin de la France le long de la Côte Méditerranéenne. Congr géol. intern. Alger, C. R. XIX, Sect. IV fasc. IV, 25-63

Hottinger, L. (1977). Distribution of larger Beneroplidae, Borelis and Nummulitidae in the Gulf of Elat, Red Sea. Utrecht Micropaleont. B. 15: 35-109

Hottinger, L. (1982). Neritic macroid genesis, an ecological approach. In: Peryt, $T$ (ed.) Coated grains. Springer Heidelberg

Klinker, J., Reiss, Z., Kropach, C., Levanon, I., Harpaz, H. Halicz, E., Assaf, G. (1976). Observations on the circulation pattern in the Gulf of Elat (Aqaba), Red Sea. Israel J. Earth Sci. 25: 85-103

Klinker, J., Reiss, Z., Kropach, C., Levanon, I., Harpaz, H., Shapiro, Y. (1978). Nutrients and biomass distribution in the Gulf of Aqaba (Elat), Red Sea. Mar. Biol. 45: 53-64

Marenzeller, E. v. (1906). Tiefseekorallen. Deutsche K. K Akad. Wissensch. Wien, Math. Natw. Kl. 80:13-25

Moore, D. R., Bullis, H. R. (1960). A deep-water coral reef in the Gulf of Mexico. Bull mar Sci. Gulf Caribb. 10 : $125-128$

Mullins, H. T., Newton, C. R., Heath, K., Vanburen, H. M (1981). Modern deep water coral mounds north of Little Bahama Bank: Criteria for recognition of Deep Water bioherms in the rock record. J. sedim. Petrol. 51. 999-1013

Paldor, N., Anati, D. A. (1979). Seasonal variations of temperature and salinity in the Gulf of Elat (Aqaba). Deep Sea Res. 26/6A: 661-672

Squires, D. F. (1965). Deep-water coral structure on the Campell Platenau, New Zealand. Deep Sea Res. 12: 785-788

Stetson, T. R., Squires, D. F., Pratt, R. M. (1962). Coral banks occurring in deep water on the Blake Plateau. Am. Mus Novit. 2114: 1-39

Teichert, C. (1958). Cold- and deep-water coral banks. Am Ass. Petr Geol. B. 42/5: 1064-1082

Wilson, J. B. (1975). 'Patch' development of the deep water coral Lophelia pertusa (L.) on Rockall Bank. J. mar. biol. Ass. U.K. 59: 165-177

Wilson, J. B. (1979). The distribution of the coral Lophelia pertusa (L.) [L. prolifera Pallas] in the North East Atlantic. J. mar biol. Ass. U.K. 59: 149-164 